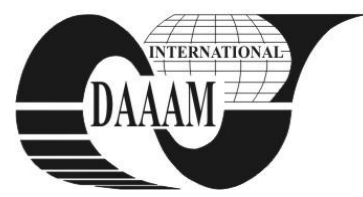

\title{
MULTICRTIERIA PRIORITIZATION OF WASTEWATER PROJECTS ON EXAMPLE OF BIHAC MUNICIPALITY
}

\author{
VUCIJAK, B[ranko] \& CERIC, A[dmir]
}

\begin{abstract}
Investments in water sector are expensive and need appropriate tools for decision aid. Paper presents one such example of investments in wastewater in Municipality of Bihac, where at first criteria were selected and valuated, then two different multicriteria ranking methods applied and results compared, in order to enable stabile decision making

Key words: multicriteria prioritization, wastewater, investments, decision making
\end{abstract}

\section{INTRODUCTION}

Investments in wastewater sector are expensive and usually it is not feasible to finance all that is needed in one municipality, region or country. Thus there is a need for prioritization of such investments, in order to maximize the results. The prioritization should be based on different criteria, and for this reason multicriteria decision aid is used. Many different techniques are employed, and only limited number is used in the water sector.

This paper presents the selection of a set of criteria for prioritizing wastewater projects in the Municipality of Bihac in Bosnia and Herzegovina, the valuation of these criteria and finally ranking the projects, using two different methodologies for comparison. Research objective is to bring a new dimension to stability of prioritization, needed for expensive decisions.

\section{METHODOLOGY}

The Municipality of Bihac is developing its wastewater services and wishes to extend this service to virtually all citizens. Within the Municipality there are 35 local communities, ten of which are already provided with partial or complete wastewater collection systems. Considering limited available financial resources, it has been realized that all communities cannot be provided with the same level of service in the short term, and that prioritization of projects is needed.

A two stage approach was used for the prioritization:

- Preliminary Screening,

- Prioritization of local communities' projects.

The preliminary screening aims at identifying the projects with zero priority and is followed by the prioritization of other projects (Eptisa/HEIS, 2008).

\subsection{Preliminary Screening}

Local communities were grouped into agglomerations for the purpose of the analysis. The analysis of agglomerations shows that at horizon 2030 the agglomeration of Bihac will have a population of about 59,000 or about $80 \%$ of the population projected for the whole municipality. Another 11,000 population $(14 \%)$ will be living in agglomerations of 2,000 or more.

This leaves about 5,000 persons living in small communities having less than 2,000 inhabitants.

Absolute priority was given to the construction of a wastewater treatment plant and the main collectors for main agglomeration of Bihac (where 33\% of the population is already provided with a collection system), so as to urgent rehabilitation projects which will improve living for those affected by the wastewater overflow from manholes.

\subsection{Prioritization of Local Communities' Projects}

The second step aimed to decide which local communities, including rural communities, are priorities to be provided with a wastewater collection system. Different methods can be used for the prioritization process and they are mostly based on a valuation system applied for selected criteria. Prioritization was based on the six main development principles (Social, Environmental, Participation, Institutional, Technology and Financial) identified at the Rio Earth Summit of 1992 and summarized in Agenda 21 (UN, 1993).

The importance of each of the selected criteria to be adapted to meet the particular needs of the Municipality through giving weights to each selected indicator, as measurable valuation of the criteria. They were grouped into socio-economic, environmental, technical and institutional preparedness, and financial.

\section{CRITERIA SELECTION AND VALUATION}

A basket of four socio-economic indicators have been identified:

- Availability of piped water supply

- Availability of services i.e. connection ratio

- Degree of urbanisation

- Participation

Piped water supply brings a large volume of water to the home which once been polluted will have to be disposed- thus higher connection to piped water supply increases the priority. Wastewater connection ratio is another important consideration because of the adverse impact to health - low wastewater connection increases priority. Degree of urbanisation is an indicator of the number of people who are likely to benefit from the project. Participation of the local community is important in making the correct choice. The Valuation boundaries were set as follows:

\begin{tabular}{|c|c|c|c|c|}
\hline $\begin{array}{l}\text { Availability of } \\
\text { piped water } \\
\text { (\% connect.): }\end{array}$ & $\begin{array}{l}\text { Wastewater } \\
\text { connection } \\
\text { rate } \% \\
\text { connect.): }\end{array}$ & $\begin{array}{l}\text { Degree of } \\
\text { Urbanization } \\
\text { (inhabitants): }\end{array}$ & $\begin{array}{l}\text { Participation } \\
\text { (no of events } \\
\text { attended): }\end{array}$ & Value \\
\hline $0-<50 \%$ & $>70-100 \%$ & $0-499$ & $0-15 \%$ & 1 \\
\hline $50-<70 \%$ & $>60-70 \%$ & $500-999$ & $>15 \%-60 \%$ & 2 \\
\hline $70-<80 \%$ & $>55-60 \%$ & $1000-1999$ & $>60 \%-80 \%$ & 3 \\
\hline $80-<90 \%$ & $>50-55 \%$ & $2000-10000$ & $\begin{array}{c}>80 \%- \\
<100 \%\end{array}$ & 4 \\
\hline $90-100 \%$ & $0-50 \%$ & $>10000$ & $100 \%$ & 5 \\
\hline
\end{tabular}

Tab. 1.Valuation of socio-economic criteria

Proximity to a major source of water supply is an environmental prioritization criterion; local communities in the proximity of the water source have higher priority.

The importance of the receiving water, determined by the amount of the receiving water and its dilution ability, and 
impact of the pollution is evaluated. Communities discharging to the Una River have lower priority and those discharging to groundwater are given the highest priority.

\begin{tabular}{|c|c|c|}
\hline $\begin{array}{l}\text { Impact to receiving water } \\
\text { (Dilution potential): }\end{array}$ & $\begin{array}{l}\text { Impact to water supply } \\
\text { (Proximity to): }\end{array}$ & Value \\
\hline Una River & Small source & 1 \\
\hline Klokot River & Gata & 2 \\
\hline Drobnica river & Ostrovica & 3 \\
\hline Road/ canal & Privilica & 4 \\
\hline Groundwater & Klokot & 5 \\
\hline
\end{tabular}

Tab. 2.Valuation of environmental criteria

Preparedness is an indicator of the urgency the administration has placed on the projects. Priority is given to projects at an advanced degree of technical preparedness.

Two financial indicators have been selected for evaluation Capital cost per capita of connection (cost effectiveness) and Local community funding. The projects with the least per capita cost will have higher priority for the higher return on the investment. The projects with the least per capita cost will have higher priority because of the higher return on the investment. During this study it was assumed that no contribution will be made by any of the communities and that all costs will be covered from grants.

\begin{tabular}{|l|c|c|c|}
\hline \multicolumn{1}{|c|}{ Preparedness } & \multicolumn{2}{|c|}{ Financial Indicators } & Value \\
\hline $\begin{array}{l}\text { Advancement of } \\
\text { projects } \\
\text { (Completed } \\
\text { study): }\end{array}$ & $\begin{array}{l}\text { Cost } \\
\text { Effectiveness(percentiles } \\
\text { of the indicator): }\end{array}$ & $\begin{array}{l}\text { Fonancial } \\
\text { Community (\% of } \\
\text { project cost): }\end{array}$ & \\
\hline No design & $>80 \%-100 \%$ & $0-<20 \%$ & 1 \\
\hline Conceptual design & $>60 \%-80 \%$ & $20 \%-<30 \%$ & 2 \\
\hline $\begin{array}{l}\text { Preliminary } \\
\text { design }\end{array}$ & $>40 \%-60 \%$ & $30 \%-<50 \%$ & 3 \\
\hline Spatial plan & $>20 \%-40 \%$ & $50 \%-<75 \%$ & 4 \\
\hline Detailed design & $<=20 \%$ & $75 \%-95 \%$ & 5 \\
\hline
\end{tabular}

Tab. 3. Valuation of Technical and Institutional Preparedness, so as Financial Indicators

Specific valuation for 37 settlements leaded to the table 4 .

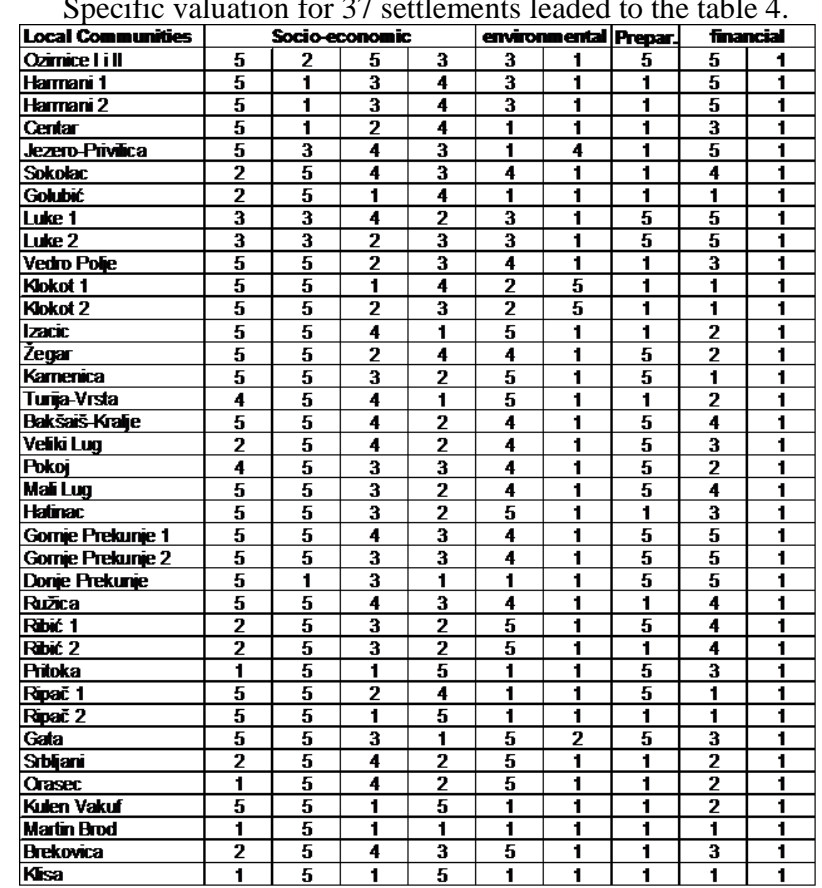

Tab. 4.Values of Criteria

\section{RANKING AND CONCLUSION}

Two different multicriteria methods were applied - first was relatively familiar method of linear summation with weight factors, with weights for the grouped criteria of $0.3,0.4,0.2$ and 0.4 respectively. This methodology ranks largest to smallest, values can be within the range 3 to 15 . First ten are ranked as:

\begin{tabular}{|l|l|c|}
\hline 1 & Gornje Prekunje 1 & 10.5 \\
\hline 2 & Gornje Prekunje 2 & 10.2 \\
\hline 3 & Bakšaiš-Kralje & 9.8 \\
\hline 4 & Gata & 9.6 \\
\hline 5 & Mali Lug & 9.5 \\
\hline 6 & Ozimice I i II & 9.5 \\
\hline 7 & Ružica & 9.3 \\
\hline 8 & Jezero-Privilica & 9.1 \\
\hline 9 & Ribić 1 & 9.0 \\
\hline 10 & Žegar & 9.0 \\
\hline
\end{tabular}

Tab. 5. Ranking priorities with linear summation method

Second method used was VIKOR (Opricovic, 1998). The method assumes that as compromise, decision maker would accept a solution that is the closest to the "ideal" solution. VIKOR has been successfully used as MCDM tool - examples refer e.g. to selection of industrial robots (Athawale et al., 2010) or selection of materials under aggressive environments (Cristóball et al., 2010). The same weights as before were applied. This methodology ranks smallest to largest, values can fall within the range 0 to 1 . First ten are ranked as follows:

\begin{tabular}{|l|l|c|}
\hline 1 & Gornje Prekunje 1 & 0.0000 \\
\hline 2 & Gornje Prekunje 2 & 0.0146 \\
\hline 3 & BakšaššKralje & 0.0585 \\
\hline 4 & Mali Lug & 0.0731 \\
\hline 5 & Ribić 1 & 0.0958 \\
\hline 6 & Gata & 0.1447 \\
\hline 7 & Jezero-Privilica & 0.2003 \\
\hline 8 & Ružica & 0.2149 \\
\hline 9 & Veliki Lug & 0.2295 \\
\hline 10 & Ozimice I i II & 0.2310 \\
\hline
\end{tabular}

Tab. 6. Ranking priorities with VIKOR method

It is visible that only one of the first ten communities differ (Žegar and Veliki Lug), so as that the sequence of order is quite similar, what all gives confidence to decision makers on their choice of preferences. Research confirmed practical usability of the valuation and multicriteria ranking methods, and their mutual comparison leads to the stable decision making.

Further research will be related to valuations and ranking using other methods so as their comparison, but also to further development of valuation methods for the selected set of criteria, including the refinement of this set.

\section{REFERENCES}

Athawale V.M.; Chatterjee P. \& Chakraborty S. (2010). Selection of Industrial Robots using Compromise Ranking Method, Proceedings of the 2010 International Conference on Industrial Engineering and Operations Management, ISBN 978-984-33-0988-4, Dhaka

Cristóbal J.R.S.; Biezma M.V.; Martínez R. and Somoza R. (2009). Selection of Materials Under Aggressive Environments: the Vikor Method, Proceedings of $3^{\text {rd }}$ International Conference on Integrity, Reliability and Failure, ISBN 978-972-8826-21-5, J.F. Silva Gomes \& Shaker A. Meguid (Ed.), Paper Ref: S1204_P0266, Porto

Eptisa/HEIS (2008). Provision of Feasibility Study for Wastewater Treatment Plant in Bihać, Wastewater Master Plan \& Feasibility Study. Eptisa Servicios de Ingenieria S.A. Spain \& Hydro-Engineering Institute Sarajevo

Opricovic, S. (1998): Višekriterijumska optimizacija sistema u građevinarstvu, Faculty of Civil Engineering, ISBN 8680049-82-4, Belgrade

UN (1993). Agenda 21: Earth Summit - The United Nations Programme of Action from Rio. United Nations, ISBN: 9211005094, New York 